\title{
Design and Development Employee Payroll Information Systems in Indeks Media Teknologi Inc.
}

\author{
Ita Arfyanti \\ STMIK Widya Cipta Dharma, Samarinda, Indonesia \\ Email: ita@wicida.ac.id \\ Rajiansyah \\ STMIK Widya Cipta Dharma, Samarinda, Indonesia \\ Email: rajiansyah@wicida.ac.id
}

Received: 02 March 2021; Accepted: 10 April 2021; Published: 08 June 2021

\begin{abstract}
The research was conducted to be able to develop an employment information system at Indeks Media Teknologi Inc. which later if this system is successful can help the company tasks when making employee payroll for each period. Research is carried out at Indeks Media Teknologi Inc.. The method of collecting data by interview asking questions related to the employee salary management system. By means of observation, namely making observations directly to the Indeks Media Teknologi Inc.. In this study, the system development method used is waterfall with the supporting software used are PHP and MySQL. The network topology used is a star topology. The results of this study are in the form of client-server based employee salary data management which can improve service and facilitate the provision of salaries for employees of Indeks Media Teknologi Inc..
\end{abstract}

Index Terms: Information Systems, Payroll, Indeks Media Teknologi Inc., Network, Client-server.

\section{Introduction}

Employee salary data processing at Indeks Media Teknologi Inc. is a very important part of a Company [1, 2, 3]. Therefore we need a system that provides convenience in planning and development in order to increase the operational performance of Indeks Media Teknologi Inc. already has a payroll system for employees, but the existing system has several shortcomings that allow for the development of a better system [4, 5]. Seeing the performance of the current employee salary data processing, namely: Employee data entry is multiuser based but cannot be used together on different computers (networks) [6], Employee salary deductions can only be deducted once in one paycheck [4, 7, 8]. If we want to deduct wages more than once, the total deduction of wages must be corrected and adjusted to the correct amount, the deduction information is incomplete because it only displays the total deductions from wages [9, 10]. Sometimes if the salary deduction statement is too long [11], the paycheck statement will not be visible or deduction (The paycheck paper is not enough) [12].The development of an employee data system is now very necessary [13, 14, $15,16,17,18]$.so that the provision of information can be carried out quickly and accurately [16, 18]. Based on the background described, in the framework of this research is the design and development employee payroll information systems at Indeks Media Teknologi Inc. Client-server based.

\section{Research Methodology}

\subsection{Requirement Definition}

This step is an analysis of software requirements, and the stage for conducting data collection by conducting meetings with employees, as well as collecting additional data both in journals, articles, and from the internet. The following is an analysis used in designing an employee payroll information system at Indeks Media Teknologi Inc.:

\section{a. Data analysis}

In designing employee payroll information systems [19, 20] at Indeks Media Teknologi Inc., obtained analysis of any data which will be processed both as input and output later. The data obtained include: 
1. Employee Data, contains employee data contained in Indeks Media Teknologi Inc.

2. Salary data, contains the amount of salary of an employee at Indeks Media Teknologi Inc.

3. Allowance data, contains the amount of a job allowance for employees of Indeks Media Teknologi Inc.

\section{b. Technology Analysis}

Technology analysis is an analysis of the software and hardware requirements [21]needed for the manufacture and design of employee payroll information systems at Indeks Media Teknologi Inc. consists of:

\section{Software}

In making this system the author uses the software (Software) as follows:

1) Windows 7 Operating System

2) Macromedia Dreamweaver MX

3) MySQL

4) PHP 5.6

5) Xampp

\section{Hardware}

In making this system the author uses the following specifications:

1) AMD A8-7410 Processor

2) 4 GB memory

3) 500 GB Hard Disk

4) Keyboard and Mouse

5) Monitor

\section{Network}

1) U(Unshielded Twisted Pair) cable category 5e

2) Straight Cable Connector

3) Connector RJ-45 (Connector Registered Jack)

4) HUB

5) Star topology network topology

\section{c. Information Analysis}

In designing employee payroll information systems at Indeks Media Teknologi Inc., obtained analysis of what information will be produced later. The information generated includes:

\section{Employee Data Information}

Information data about employees contained in Indeks Media Teknologi Inc.

\section{Salary Data Information}

Information about employee salary data on Indeks Media Teknologi Inc.

\section{Support Data Information}

Information about employee benefits data at Indeks Media Teknologi Inc..

\subsection{System and Software Design}

At this stage it aims to provide an outline of the form of the system to be built, and also make it easier to understand the running of the system and understand the program.

\section{a. Flow of Document (FOD) in progress}

Flow of Document (FOD) The current flow of documents (FOD) at Indeks Media Teknologi Inc. begins with the employee who provides the data to the Secretary. From the data provided by the employees, the Secretary then performs employee data processing by processing job data, employee data and data periods so as to produce employee data reports and provide these reports to the President Director and Treasurer and archive the reports. From the employee data report provided by the Secretary, the Treasurer then calculates the salary by processing employee data reports, basic salary data, benefits data and employee benefits data which results in a payroll report which is then given to the financial management and President Director and archives the report. From the salary list report that has been made, the treasurer then processes year-end salaries so as to produce a year-end salary report to be submitted to the President Director and archived by the Treasurer. 
Furthermore, from the payroll report that has been prepared by the treasurer, the financial management will process the report so as to produce a paycheck which is then given to each employee and the financial manager filing the data can be seen in Fig. 1.

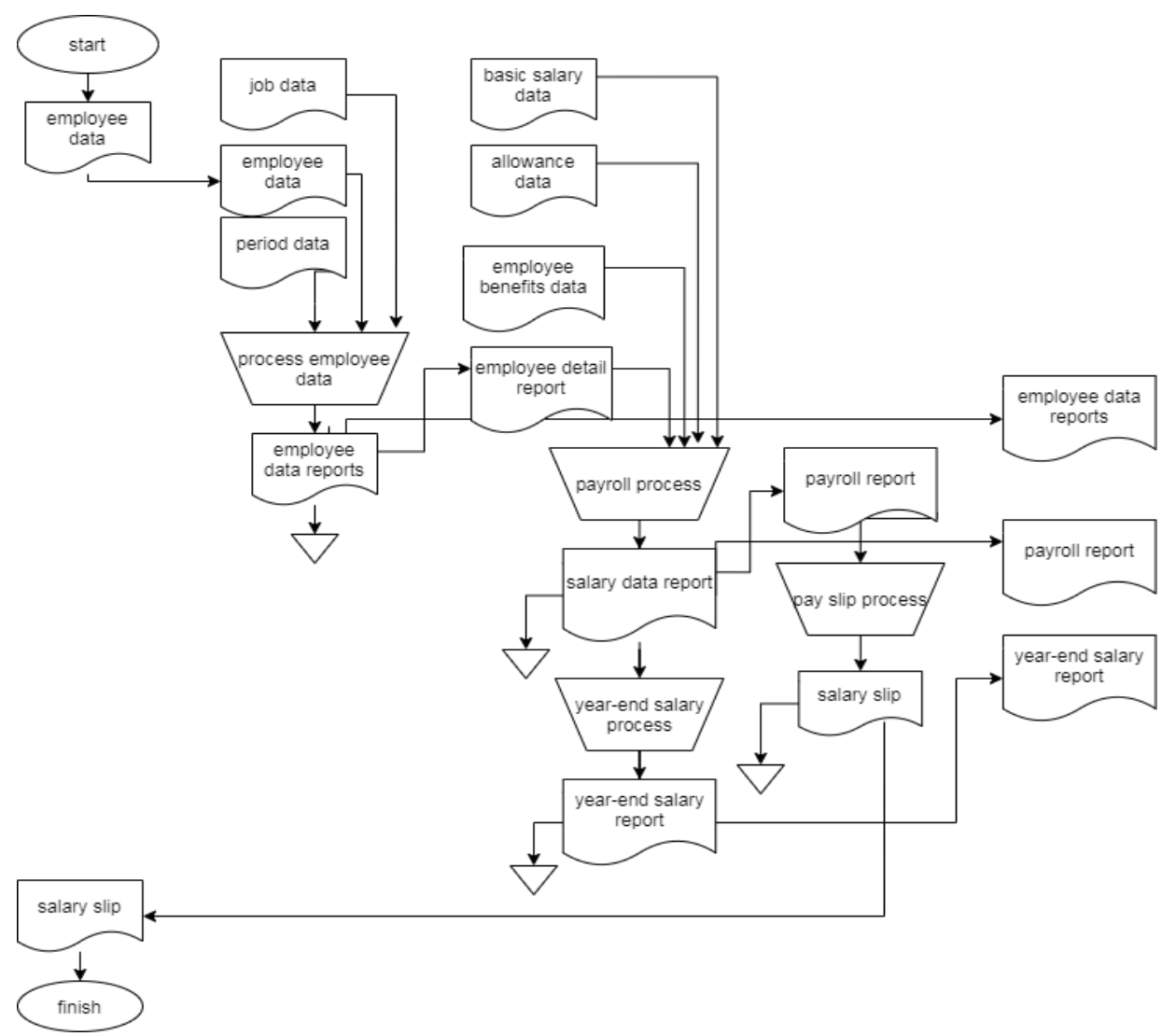

Fig. 1. Flow of Document (FOD) in progress

\section{b. Flow of Document (FOD) Proposed}

Flow of Document (FOD) proposed in the Indeks Media Teknologi Inc. begins with the Secretary inputting job data which is then processed and stored in the position table, employee data input is then processed and stored in the employee table and period data input is then processed and stored in the period table. Furthermore, after all the data has been processed. The secretary then processes the employee data obtained from the position and employee tables which are then processed and stored in the employee_detail table. After all these processes have been completed, the Secretary can process the employee list report obtained from the employee_detail table and the report will be submitted to the President Director.

Furthermore, the treasurer inputs basic salary data and is processed and stored in the payroll table, the allowance data input is processed and stored in the allowance table, the employee allowance input is processed and stored in the employee_support table. After all the data has been processed, the Treasurer will process the payroll obtained from the payroll, allowances, employee_support and employee_detail tables that have been processed by the Secretary then all the data is processed and stored in the salary_list table. After all these processes have been completed, the treasurer can process the salary list report and year-end salary report obtained from the salary_list table and the report will be given to the President Director.

Furthermore, the financial management performs the processing of the paycheck obtained from the salary-list table resulting in the paycheck given to employees, which can be seen in Fig. 2. 


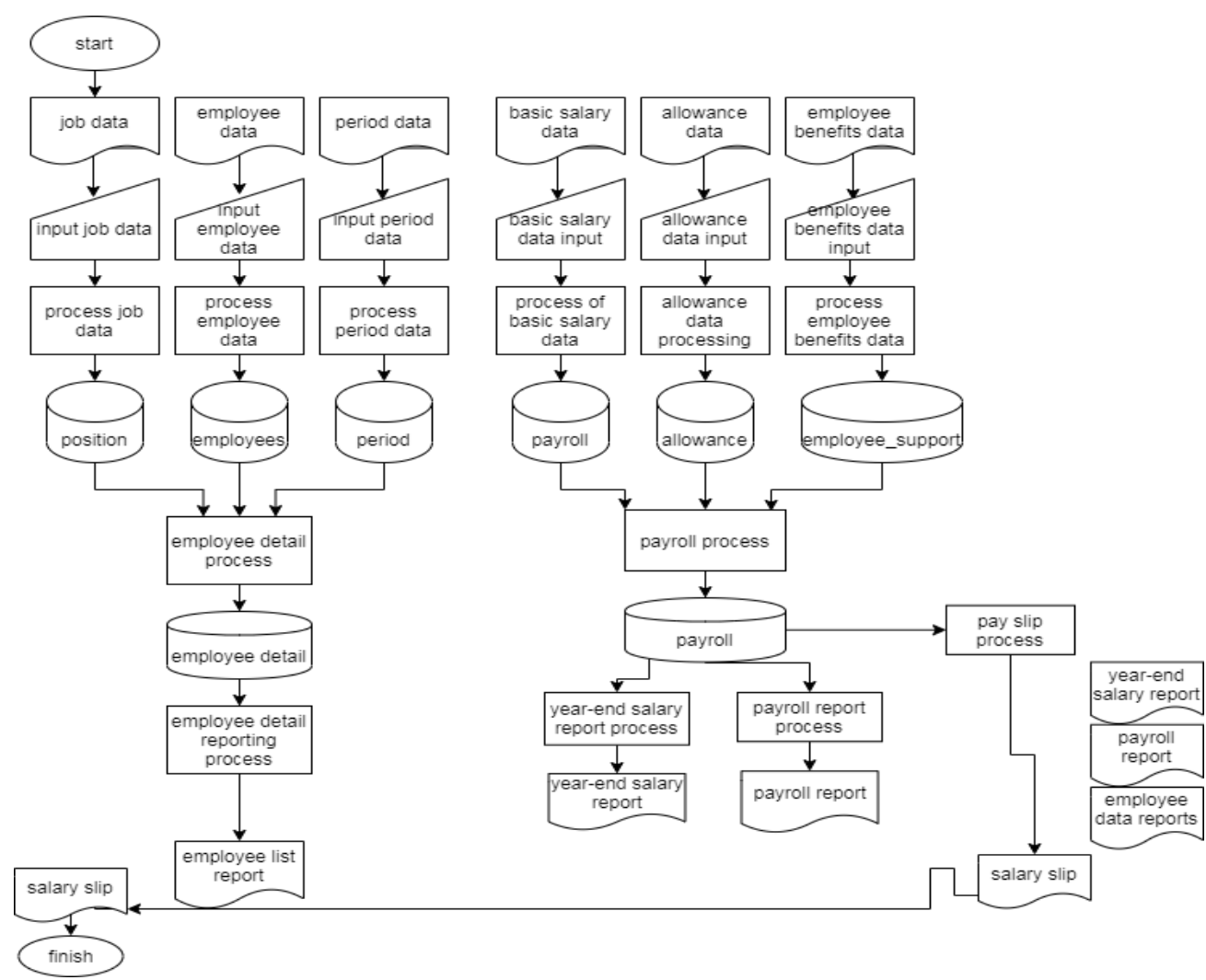

Fig. 2. Flow of Document (FOD) Proposed

\section{c. Context Diagram $(C D)$}

Context Diagram consists of 4 entities, namely the Secretary, Treasurer, President Director and Employees. The Secretary entity provides job, employee and period data. The Treasury Entity provides data on basic salaries, benefits and employee benefits. The President Director entity receives reports on payroll, employees and year-end salary reports. The employee entity receives a paycheck can be seen in Fig. 3.

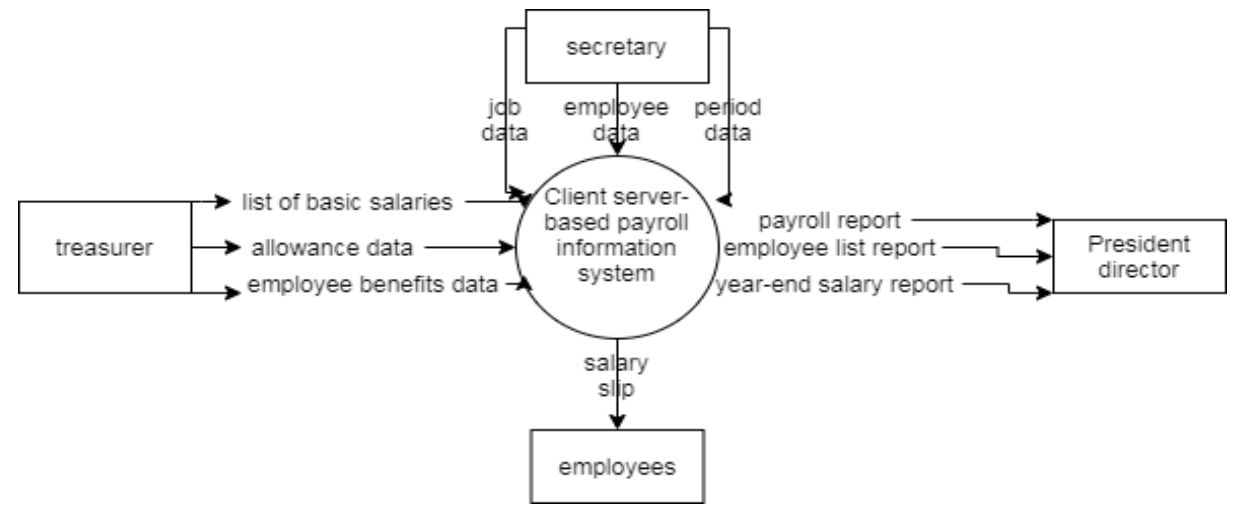

Fig. 3. Context Diagram

\section{d. Data Flow Diagram (DFD) Level 0}

Data Flow Diagram (DFD) Level 0 consists of eight processes, namely the Secretary Entity processes the job data stored in the position datastore, employee data is stored in the employee datastore, period data is stored in the period datastore and employee detail processes are obtained from the position datastore, employee datastore and stored period datastore in the employee_detail datastore.

The Treasury Entity processes the basic salary data stored in the payroll datastore, the allowance data is stored in the allowances datastore, the employee benefits data is stored in the employee_support datastore, and the payroll processes that are obtained from the payroll datastore, the allowance datastore, the employee_supportment data and the employee_sage_details are stored in the payroll datastore. The last process is a report process that produces employee 
list reports, payroll reports, year-end salary reports given to the President Director entity and paycheck given to employees can be seen in Fig. 4.

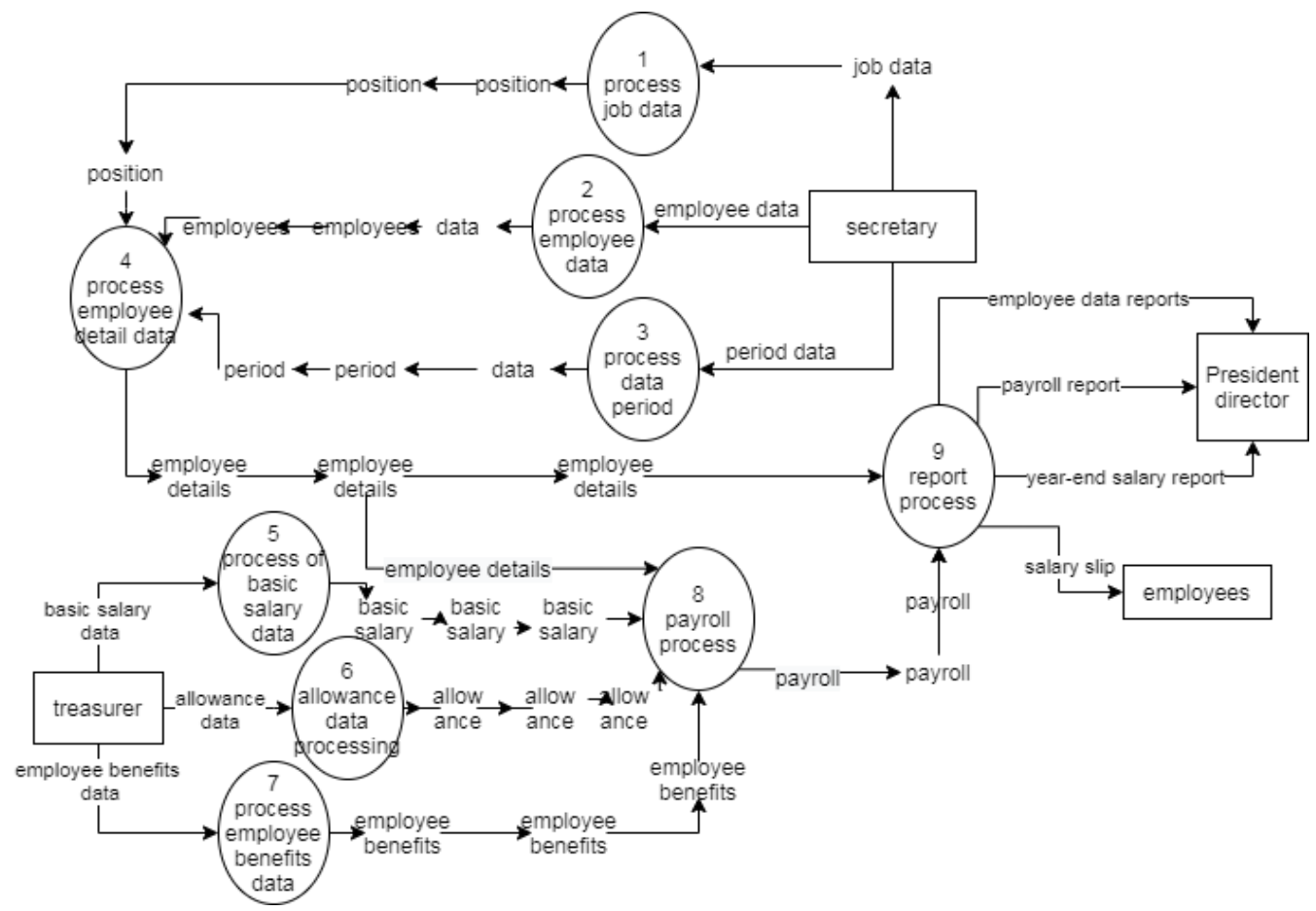

Fig. 4. Data Flow Diagram (DFD) Level 0

\section{e. $\quad$ Data Flow Diagram (DFD) Level 1}

The report process has 4 processes, namely, the employee list report process obtained from the employee_detail datastore produces a employee list report then is given to the President Director, the salary list report process obtained from the salary list datastore produces a payroll report then is given to the President Director, the final salary report process The year that is obtained from the salary_list datastore produces a year-end salary report then it is given to the President Director, and the last process of the paycheck obtained from the salary_list datastore produces a paycheck which is then given to the employees can be seen in Fig. 5

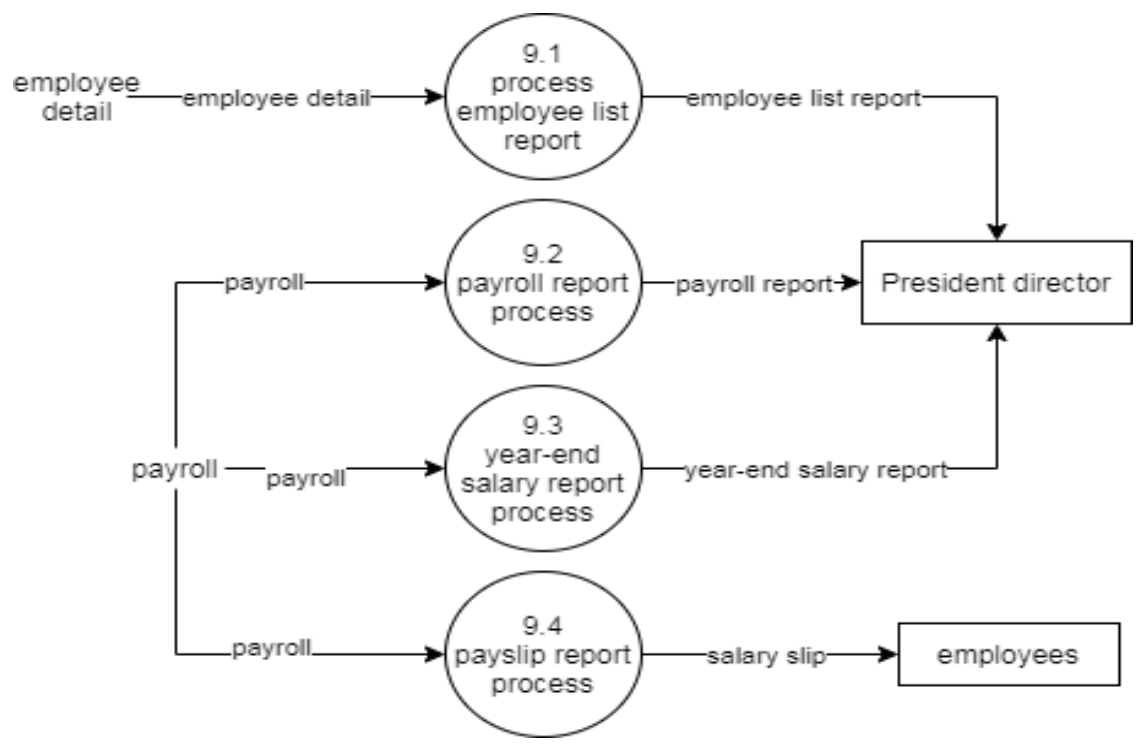

Fig. 5.Data Flow Diagram (DFD) Level 1

\section{f. Hierarchy Plus Input-Process-Output (HIPO)}


Hierarchy Plus Input-Process-Output (HIPO) in Indeks Media Teknologi Inc.'s Employee Payroll Information System consists of employee data input, employee detail data, job data, basic salary data, allowance data, employee allowance data and period data. The process consists of a payroll process. The output consists of employee list reports, payroll reports, year-end salary reports and payroll reports which can be seen in Fig. 6 .

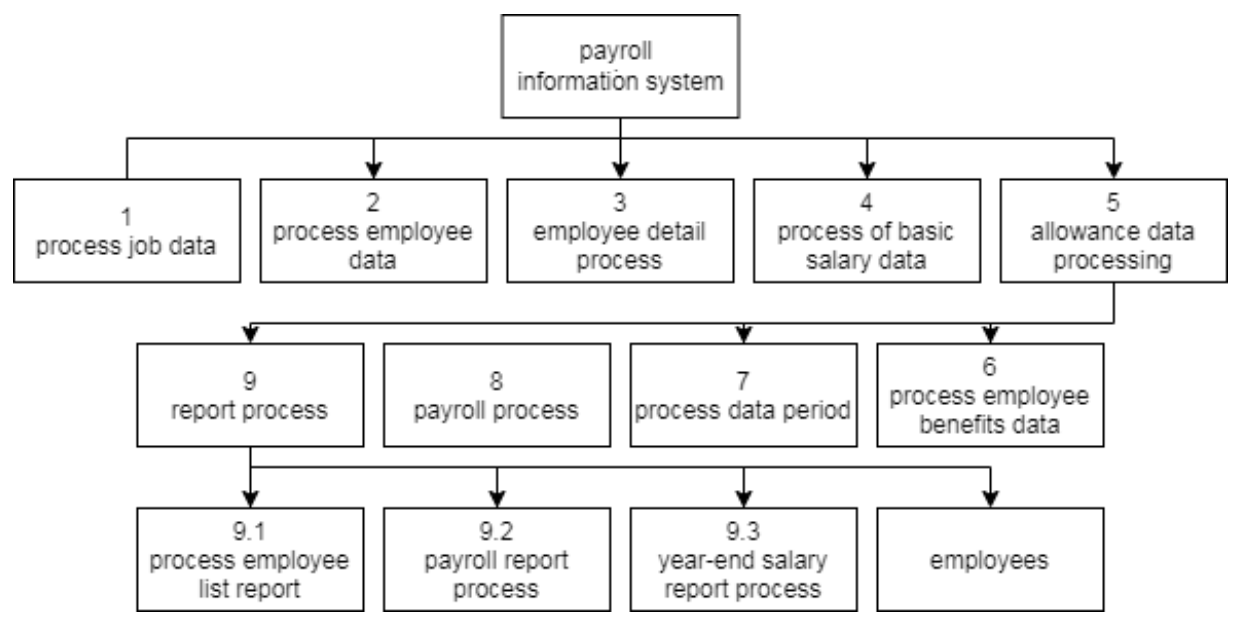

Fig. 6.Hierarchy Plus Input-Process-Output (HIPO)

\section{g. Database}

It can be seen in Table 1 that the employee table functions save the employee data.

Table 1.Employees Table Design

\begin{tabular}{|c|c|c|c|c|}
\hline No. & Field Name & Type & Size & Information \\
\hline 1 & ID & Varchar & 20 & Employee ID number \\
\hline 2 & Name & Varchar & 100 & Employee name \\
\hline 3 & Gender & Enum & L, P & Employee gender \\
\hline 4 & Born & Varchar & 100 & Place of birth of the employee \\
\hline 5 & Birthdate & Date & - & Employee's date of birth \\
\hline 6 & Religion & Varchar & 45 & Employee Religion \\
\hline 7 & Address & Text & - & Employee Address \\
\hline 8 & Marital status & Varchar & 45 & Marital status \\
\hline 9 & Number of children & Integer & 4 & Number of children \\
\hline 10 & Phone & Varchar & 17 & Phone number \\
\hline 11 & Job title & Integer & 3 & Position code \\
\hline 12 & Photo & Varchar & 100 & Employee Photos \\
\hline 13 & Username & Varchar & 100 & Employee login username \\
\hline 14 & Password & Varchar & 100 & Employee login password \\
\hline 15 & Active & Enum & $\mathrm{Y}, \mathrm{N}$ & Employee active status \\
\hline 16 & Basic salary & Integer & 11 & Employee basic salary \\
\hline
\end{tabular}

Can be seen in Table 2 is a functioning payroll tablesave payroll data.

Table 2.Payroll Table Design

\begin{tabular}{|c|c|c|c|c|}
\hline No. & Field Name & Type & Size & Information \\
\hline 1 & payroll & Varchar & 11 & Payroll code \\
\hline 2 & Basic salary & Integer & 11 & Employee basic salary \\
\hline 3 & piece & Integer & 11 & Salary cuts \\
\hline 4 & attendance & Integer & 11 & the number of employee absences \\
\hline 5 & status & Varchar & 20 & Employee status \\
\hline 6 & Period id & Varchar & 10 & Period code \\
\hline 7 & ID & Varchar & 20 & Salary receidate \\
\hline 11 & Received date & Date & & Hours of receiving wages \\
\hline 12 & Time_received & Time & & \\
\hline
\end{tabular}

Can be seen in Table 3 is a functioning employee_support table store employee benefits data. 
Table 3.Employee Benefits Table Design

\begin{tabular}{|c|c|c|c|c|}
\hline No. & Field Name & Type & size & information \\
\hline 1 & Employee_support IDs & Integer & 11 & Support code \\
\hline 2 & ID & varchar & 20 & Employee ID number \\
\hline 3 & id allowance & Integer & 11 & Support code \\
\hline 4 & amount & Integer & 11 & Amount of allowance \\
\hline
\end{tabular}

Can be seen in Table 4 is a table of allowances which functions to store the name of employee benefits.

Table 4.Allowance Table Design

\begin{tabular}{|c|c|c|c|c|}
\hline No. & Field Name & type & size & information \\
\hline 1 & id allowance & integer & 11 & Support code \\
\hline 2 & allowance & varchar & 45 & Name of benefit \\
\hline
\end{tabular}

Can be seen in Table 5 is a table of positions which functions to store data on the names of employees' positions.

Table 5.Position Table Design

\begin{tabular}{|c|c|c|c|c|}
\hline no & Field Name & type & size & information \\
\hline 1 & id position & integer & 3 & Position code \\
\hline 2 & position & varchar & 45 & Position name \\
\hline
\end{tabular}

It can be seen in Table 6 that the period table functions to store data for the period of the payroll month.

Table 6.Period Table Design

\begin{tabular}{|c|c|c|c|c|}
\hline no & Field Name & type & size & information \\
\hline 1 & id period & integer & 3 & Period code \\
\hline 2 & Month & varchar & 25 & Month name \\
\hline 3 & year & varchar & 4 & Year number \\
\hline 4 & active & enum & Y, N & Period active status \\
\hline
\end{tabular}

It can be seen in Table 7 that the users table functions to store user data.

Table 7.Users Table Design

\begin{tabular}{|c|c|c|c|c|}
\hline No. & Field Name & Type & Size & Information \\
\hline 1 & iduser & integer & 11 & Users code \\
\hline 2 & username & varchar & 100 & Username login \\
\hline 3 & password & varchar & 100 & User login password \\
\hline 4 & name & varchar & 45 & Username \\
\hline 5 & phone & varchar & 17 & User's phone number \\
\hline
\end{tabular}

Can be seen in Table 8 is a detail employee table which functions to store all detail employee data.

Table 8.employee_detail Table Design

\begin{tabular}{|c|c|c|c|c|}
\hline No. & Field Name & Type & Size & Information \\
\hline 1 & employee_detail id & Varchar & 20 & Detail Employee ID \\
\hline 2 & Job title & Integer & 3 & Position code \\
\hline 3 & ID & Varchar & 20 & Employee ID number \\
\hline 4 & Name & Varchar & 100 & Employee name \\
\hline 5 & Marital status & Varchar & 45 & Marital status \\
\hline 6 & Number of children & Integer & 4 & Number of children \\
\hline 7 & Information & Varchar & 20 & Information \\
\hline 8 & Detailed_note & Text & - & Fill in the description \\
\hline 9 & Status_data & Integer & 2 & Data Status \\
\hline
\end{tabular}

Can be seen in Table 9 is a payroll table that functions to store detailed salary list data.

Table 9. List of salaries Table design

\begin{tabular}{|c|c|c|c|c|}
\hline No. & Field Name & Type & Size & Information \\
\hline 1 & ID_salary & Varchar & 20 & No Circular Salary \\
\hline 2 & month & Varchar & 12 & Month \\
\hline 3 & year & Varchar & 4 & Year \\
\hline 4 & ket_gaji & Varchar & 12 & Information \\
\hline
\end{tabular}




\section{h. Network Architecture}

At this stage, the implementation of a computer network installation at Indeks Media Teknologi Inc. is carried out with the network topology used is a star topology can be seen in Fig. 7.

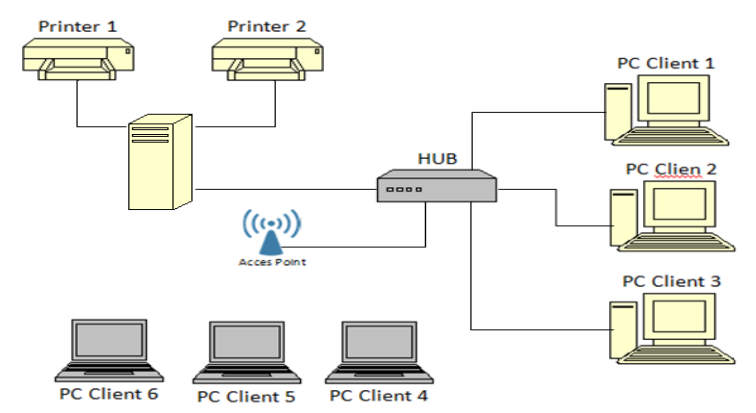

Fig. 7. Network Architecture

\section{Results and Discussion}

\subsection{Login View}

The login display that can be seen in Fig. 8 is a login page display on the design of the employee salary data processing system at Indeks Media Teknologi Inc.. The login page contains a username, password and user level form. Username is filled in according to the user that has been registered previously, the password is filled in according to the user who will log in and the level is selected according to the user's access rights.

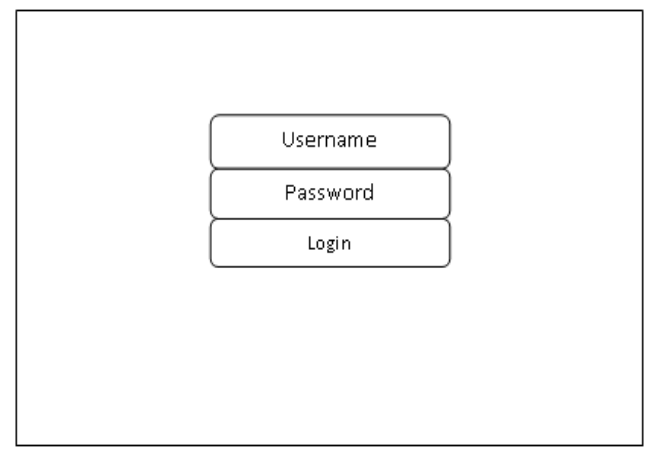

Fig. 8. Login Page Views

\subsection{Input page}

\section{a. Period Pages}

The period page view that can be seen in Fig. 9 is a period input page display on the design of the employee payroll information system at Indeks Media Teknologi Inc.. This page functions to add payroll periods to Indeks Media Teknologi Inc..

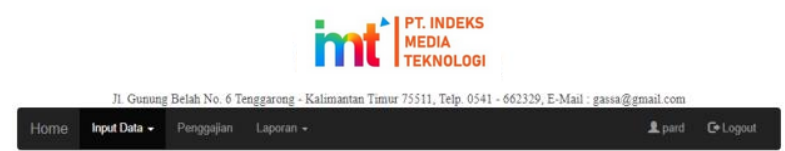

Penambahan Masa Periode Penggajian

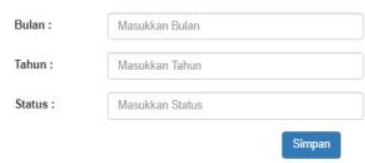

Fig. 9. Period input page

b. Position page 
The job page display that can be seen in Fig. 10 is a page display of the Position input in designing an employee payroll information system at Indeks Media Teknologi Inc.. This page functions to add job data at Indeks Media Teknologi Inc..

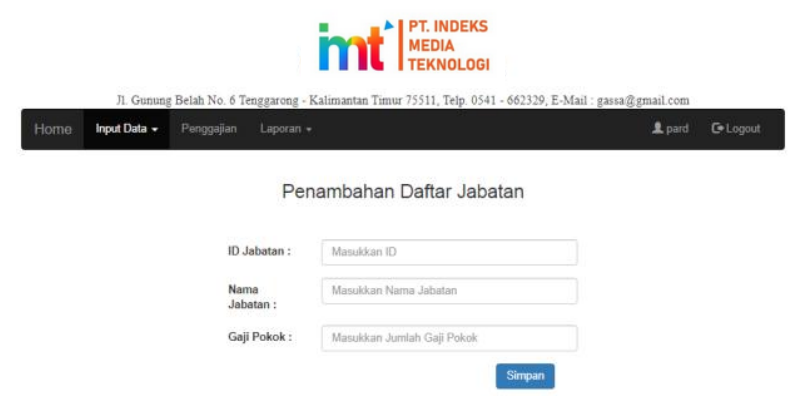

Fig. 10. Position page

\section{c. Employee Page}

The employee page display that can be seen in Fig. 11 is a display of the Employee input page in designing an employee payroll information system at Indeks Media Teknologi Inc.. This page functions to add a list of employees at Indeks Media Teknologi Inc..

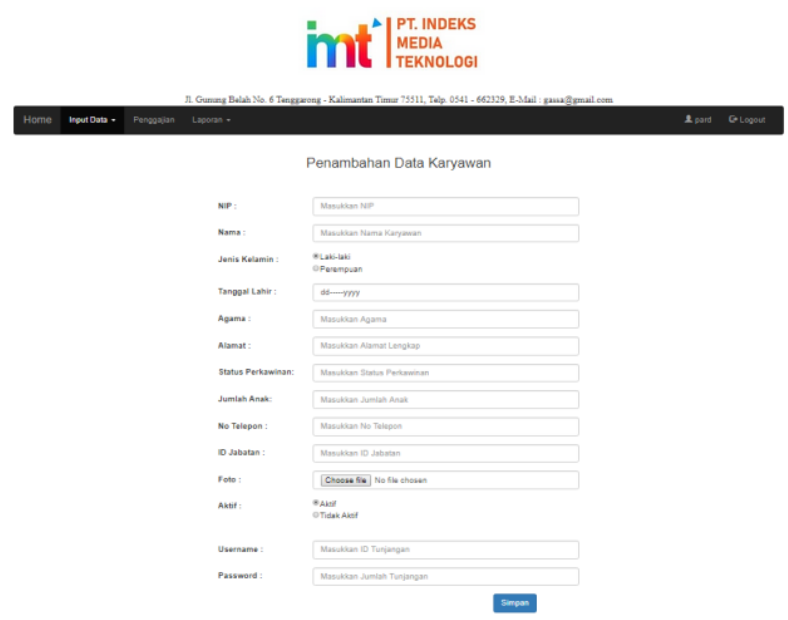

Fig. 11. Employee Input page

\section{d. Employee Benefits page}

The appearance of the employee benefits page which can be seen in Fig. 12 is a page display of employee benefits input in designing an employee payroll information system at Indeks Media Teknologi Inc.. This page serves to add a list of employee benefits at Indeks Media Teknologi Inc..
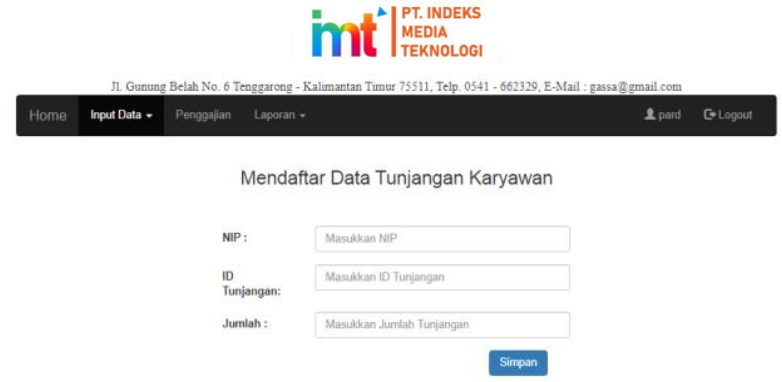

Fig. 12. Employee Benefits Input page
3.3 Process page
a. Payroll page 
The payroll page display that can be seen in Fig. 13 is a display of the payroll page in designing an employee payroll information system at Indeks Media Teknologi Inc.. This page contains a list of employees and also salaries based on absenteeism, benefits, and deductions which can be viewed by selecting the detailed options on the website.

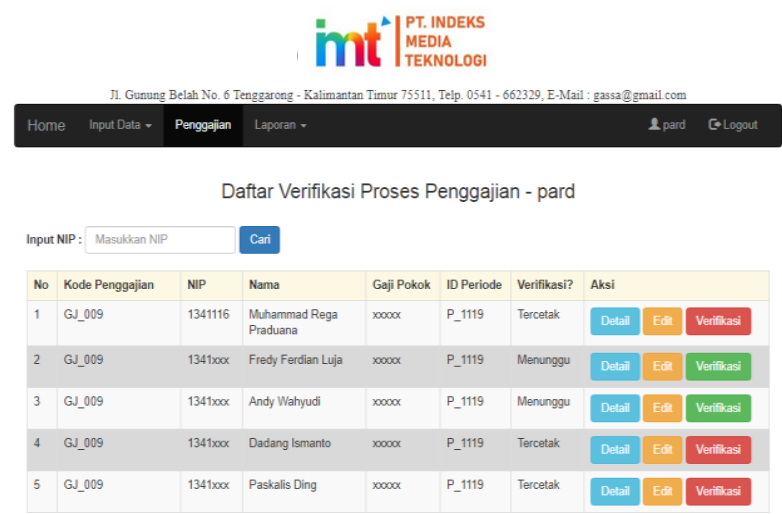

1

Fig. 13. Payroll Processing Verification page

\subsection{Output Report}

\section{a. Employee List Report page}

The employee list report display which can be seen in Fig. 14 is a display of the employee list report at Indeks Media Teknologi Inc. which is obtained from the results of previous employee data input on the employee input page.

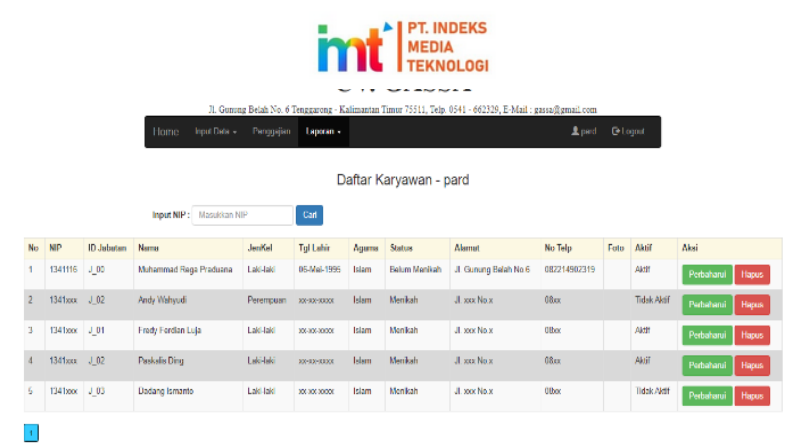

Fig. 14. Employee list report page

\section{b. Payroll Report page}

The display of the payroll report or salary recap which can be seen in Fig. 15 is a display of the payroll report on Indeks Media Teknologi Inc.. This page contains detailed payroll results including paycheck number, ID, employee name, basic salary, amount of allowance, total net salary and the last column, namely initials filled in by employees who have received paycheck.

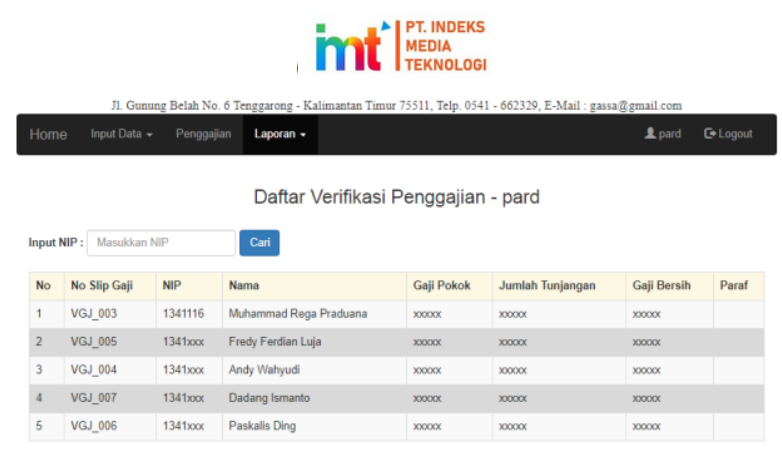

1

Fig. 15.Payroll Report page 


\section{c. Paycheck}

The display of employee paycheck which can be seen in Fig. 16 is a display of employee paycheck at Indeks Media Teknologi Inc.. This page displays the form of employee paycheck which will be printed if it has been verified on the payroll process verification page.

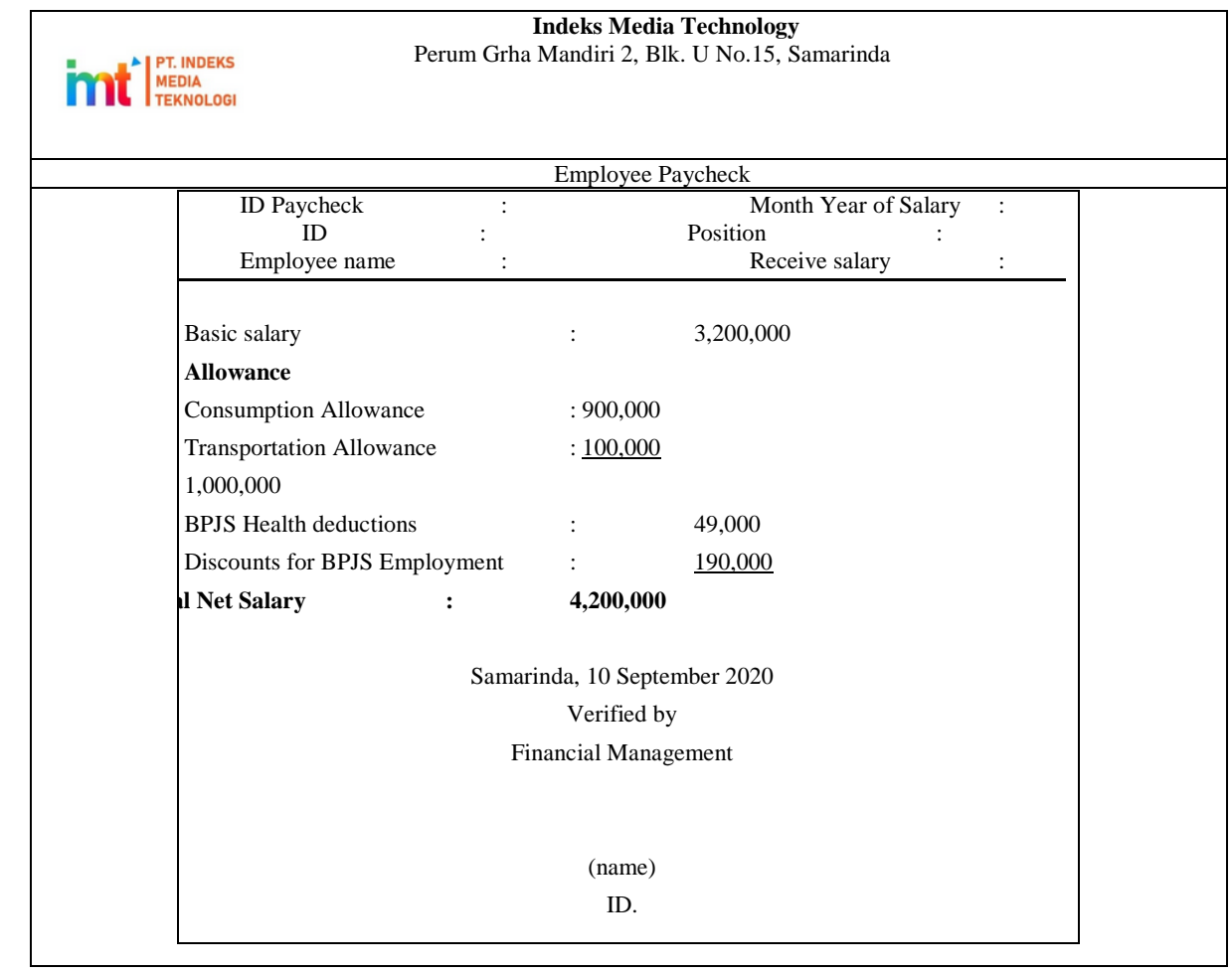

Fig. 16. Employee Paycheck

\section{Conclusion}

With the development of a client server-based employee payroll system, it can simplify the process of data entry, data search, data transactions and data reporting together through the network. In addition, it can also save time in making reports and printing paychecks. Avoid errors in calculating the payment of allowances. Data resulting from the system can be directly used by parties in need, in this case by the treasury section who uses this system. This design can be implemented and used in the company Indeks Media Teknologi Inc. and adapted to the needs of employees' payroll.

\section{References}

[1] F. Bintoro, "Data Processing System Information on Employee Salary Perum Prasarana Perikanan Samudra Jakarta Using Visual Basic 6.0," Faculty of Computer Science and Information Technology, 2011.

[2] D. Tomaskovic-Devey, M. Hällsten dan D. Avent-Holt, "Where Do Immigrants Fare Worse? Modeling Workplace Wage Gap Variation with Longitudinal Employer-Employee Data," American Journal of Sociology, vol. 120, no. 4, pp. 1095-1143, 2015.

[3] R. Taufiq, D. Kasoni, C. Siswoko dan L. Liesnaningsih, "Rancang Bangun Aplikasi Penggajian Menggunakan Hybrid Mobile Programming di CV Agung Glass," Jurnal Informatika Universitas Pamulang, vol. 5, no. 3, pp. 334-341, 2020.

[4] I. Budimir, I. Grgić dan M. Šljivarić, "Comparative Analysis Of Several Existing Gnss System," Naučna revija, Časopis Evropskog univerziteta Kallos, Tuzla za medicinske i tehničke nauke, vol. 1, no. 1, pp. 89-105, 2016.

[5] Y. Yuan dan W. Banzhaf, “An Evolutionary System for Better Automatic Software Repair,” GPTP, pp. 383-406, 2020.

[6] A. I. Mueller, D. Osterwalder, J. Zweimüller dan A. Kettemann, "Vacancy Durations and Entry Wages: Evidence from Linked Vacancy-Employer-Employee Data,", 2018.

[7] I. M. D. P. Asana, I. G. I. Sudipa dan I. M. A. Wijaya, "Decision Support System For Employee Assessment At PT. Kupu-Kupu Taman Lestari Using AHP And BARS Methods: Decision Support System For Employee Assessment At PT. Kupu-Kupu Taman Lestari Using AHP And BARS Methods,"Jurnal Mantik, vol. 4, no. 1, pp. 97-106, 2020.

[8] O. '. Arogundade, B. Ojokoh, M. G. Asogbon, O. W. Samuel dan B. S. Adeniyi, "Fuzzy Driven Decision Support System for Enhanced Employee Performance Appraisal," International Journal of Human Capital and Information Technology Professionals, vol. 11, no. 1, pp. 17-30, 2020. 
[9] M. Rowland, S. Omidshafiei, K. Tuyls, J. Perolat, M. Valko, G. Piliouras dan R. Munos, "Multiagent Evaluation under Incomplete Information," dalam Advances in Neural Information Processing Systems, arXiv preprint arXiv:1909.09849. 2019.

[10] N. Vélez dan H. Gweon, "Integrating Incomplete Information With Imperfect Advice.," Topics in Cognitive Science, vol. 11, no. 2, pp. 299-315, 2019.

[11] H. Choma dan T. Kgarabjang, "Application Of Audi Alteram Partem Rule On Salary Deduction \& Benefits,” Risk Governance and Control: Financial Markets \& Institutions, vol. 8, no. 3, pp. 61-69, 2018.

[12] N. Bajkalova, "Salary: accrual and deduction," Landscape Journal, 2019.

[13] H. Carter-Templeton, G. F. Templeton, L. G. Cole dan B. A. Graves, "Development of a Dashboard to Monitor Employee Wellness Data," Sigma's 30th International Nursing Research Congress, 2019.

[14] J. Liu, J. Huang, T. Wang, L. Xing dan R. He, "A Data-Driven Analysis of Employee Development Based on Working Expertise," IEEE Transactions on Computational Social Systems, pp. 1-13, 2021.

[15] O. M. Ababneh, M. LeFevre dan T. Bentley, "Employee engagement: development of a new measure," International Journal of Human Resources Development and Management, vol. 19, no. 2, pp. 105-134, 2019.

[16] G. Cormier, F. Gino, P. I. Green, J. Chatman, L. John, D. Southwick, D. Tussing, R. Boghrati, A. Duckworth, L. Jang, A. Quirk, C.-J. Tsay dan L. Ungar, "The Future of Employee Development: Fostering Developmental Relationships and Addressing Barriers," Academy of Management Proceedings, vol. 2020, no. 1, p. 17232, 2020.

[17] N. A. Tsareva dan S. Y. Omelyanenko, "Remote work: development of employee digital competence," Revista de la Universidad del Zulia, vol. 11, no. 31, pp. 131-140, 2020.

[18] J. Wang, D. Li, Z. Wang dan T. Wan, "Research on Enterprise Employee Information System Based On Big Data Analysis," Journal of Physics: Conference Series, vol. 1748, p. 32025, Routledge. 2021.

[19] J. Pallant, SPSS Survival Manual: A Step by Step Guide to Data Analysis Using IBM SPSS, 2020.

[20] D. A. Kenny, D. A. Kashy dan W. L. Cook, Dyadic Data Analysis, Guilford press, 2020.

[21] B. Commoner, The Closing Circle: Nature, Man, and Technology, Courier Dover Publications.,2020.

\section{Authors' Profiles}

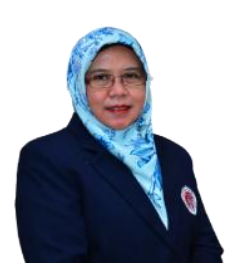

Ita Arfyanti, S.Kom., M.M, was born in Jakarta on September 23, 1971. Completed formal education in elementary school (1984), junior high school (1987), in Samarinda, East Kalimantan and senior high school (1990) in Surakarta. Continuing Bachelor Studies at Gunadarma School of Information Management (STMIK) Jakarta, Informatics Management graduated (1995), and Masters studies at Bina Nusantara University (BINUS) Jakarta. Master in Information Systems Management graduated (2005). Thesis: Knowledge Management System Design at PT. Aprisma for Overcoming Discontinuity of Knowledge. Lecturer at Widya Cipta Dharma College of Information Management (STMIK) Samarinda, East Kalimantan Province. Since 1995 until now, and also served as vice-rector for general affairs and finance.

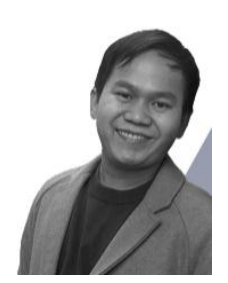

Rajiansyah, S.Kom., M.Sc Born in Balikpapan, June 6, 1991. He has completed his master of degrees at the Faculty of Computer Science and Management, Department of Computer Science, Information Systems Specialization, Wrocław University of Science and Technology, Poland in 2018. He aspires to build education in Indonesia, especially in Kalimantan, to be better and useful for the people around. Now, he is a lecturer at STMIK Widya Cipta Dharma and CEO at Indeks Media Teknologi Inc.

How to cite this paper: Ita Arfyanti, Rajiansyah, " Design and Development Employee Payroll Information Systems in Indeks Media Teknologi Inc.", International Journal of Information Engineering and Electronic Business(IJIEEB), Vol.13, No.3, pp. 1-12, 2021. DOI: $10.5815 /$ ijieeb.2021.03.01 